\title{
Subtitling Strategies of Po's Utterances in Kung Fu Panda Movie
}

\author{
${ }^{1}$ Hiroka Putra Adinusa, ${ }^{2}$ Rahmanti Asmarani \\ ${ }^{1,2}$ Universitas Dian Nuswantoro, Semarang \\ (hiroka.ardinusa@gmail.com)
}

Article History: Submitted 25 April 2018; Accepted 2 May 2018; Published date 28 June 2018

\begin{abstract}
This research is entitled "Subtitling Strategies of Po's Utterances in Kung Fu Panda Movie". The aim of this research is to find out the subtitling strategies of Po's Utterances in Kung Fu Panda Movie. This research used descriptive qualitative method to describe then analyze the subtitling strategies of Po's utterances in Kung Fu Panda movie. The steps of analyzing data are: collecting the data, identifying the data, classifying the data, analyzing the data, and the last step is drawing the conclusion. Transfer strategy has the most frequency in Po's utterances in Kung Fu Panda movie, the percentage reaching 53,91\% over half of Po's utterances. Transfer strategy is translated more easily because this strategy translating the source language completely and accurately into the target language. So it is easy to make the audience understand from the source language to the target language with the original meaning from this movie. Meanwhile, transcription has the least frequency in Po's utterances, the percentage is $2,90 \%$. Transcription strategy is found rarely because this strategy is used to translate a language when there exist unusual term in the source language (SL), like nonsense language and third language. So it is difficult to find out transcription strategy in Kung Fu Panda movie.
\end{abstract}

Keywords: Subtitling Strategies, Transcription, Transfer, Utterances

Abstrak. Penelitian ini berjudul "Strategi Penerjemahan pada Ujaran Po sebagai tokoh utama di Film "Kung Fu Panda" dengan tujuan untuk mengetahui strategi penerjemahan ujaran Po di film Kung $\mathrm{Fu}$ Panda. Penelitian ini menggunakan metode deskriptif kualitatif untuk menjelaskan dan menganalisis strategi penerjemahan ujaran Po di film "Kung Fu Panda". Tahapan-tahapan analisis adalah : mengumpulkan data, mengidentifikasi data, mengelompokkan data, menganalisis data, dan tahap terakhir adalah mengambil kesimpulan. Strategi transfer memiliki frekuensi paling tinggi dalam ujaran Po di film Kung Fu Panda, dengan persentase mencapai 53,91\% lebih dari setengah ujaran Po. Strategi transfer merupakan strategi yang lebih mudah digunakan karena strategi ini menerjemahkan bahasa sumber secara lengkap dan akurat ke dalam bahasa sasaran. Jadi lebih mudah untuk membuat penonton mengerti bahasa sumber ke bahasa target melalui makna asli dari film tersebut. Sementara, transkripsi memiliki frekuensi terendah dalam ujaran Po, persentasenya 2,90\%. Strategi transkripsi jarang ditemukan karena strategi ini digunakan untuk menerjemahkan bahasa ketika ada istilah yang tidak biasa dalam bahasa sumber (BS), seperti kata-kata yang tidak bermakna atau bahasa lain. Dengan demikian strategi transkripsi tidak banyak ditemukan dalam film "Kung Fu Panda" ini.

Kata kunci: strategi penerjemahan, transkripsi, transfer, ujaran 


\section{INTRODUCTION}

Each country has a different requirement when it comes to translating film, the major of translation modes is subtitling. Subtitling is supplying a translation of the spoken source language dialogue into the target language in the form of synchronized captions, usually at the bottom of the screen, is the form that alters the source text to the least possible extent and enables the target audience to experience the foreign and be aware of its foreignness at all times (Szarkowska, 2005:2). From this definition it can be concluded that subtitling aims to make audience feel the story experience, then to get the message in the target language simultaneously.

In short, subtitling translates the pronunciation in the source language (SL) into written language in the target language (TL). Most popular movies come from Hollywood and English speaking countries like USA (United States of America) and United Kingdom (England). So, subtitling is one of the most important things in movies, because subtitling has given many benefits in movies or films. For example, it is very helpful to understand the message from the source language (English) to the target language (Indonesian language) on the subtitle of the movie screen. With subtitling, the audience can enjoy the foreign movies or films by reading the translated subtitle of the movie screen without having misunderstanding.

Translation is a process of conveying meanings from source language (SL) to another language positioned as the target language (TL), which is used here from the source language (English) into the target language (Indonesian language). Based on the theory from (Newmark, 1981:7) Translation is "a craft consisting in the attempt to replace a written message or statement in one language by the same message or statement in another language". Translating the dialogue from the source language (SL) into the target language (TL) in the movies is not easy assignment for the translator. A good subtitle is when the translator can bring the viewer to the same experience as well as the original viewer (Nornes, 1999:4). Translation is replacement process of textual material in source language (SL) by equivalent textual material in target language (TL), which it can be in the verbal or textual manner, with two different languages. There are several definitions of translation that have been stated by several experts. One of the definition is from Mildred Larson (1991:17) stated that the ideal translation will be accurate as to meaning and natural as to the receptor language forms used. The success of a translation is measured by how closely it measures up to these ideals. The ideal translation can be summed up as follows:

1. Accurate (reproducing as exactly as possible the meaning of the source text).

2. Natural (using natural form of the receptor language in a way that is appropriate to the kind of text being translated).

3. Communicative (expressing all aspects of the meaning in a way that is readily understable to the intended audience).

Furthermore is translation process. Translation process is a process to make a right translation in translation study. According to Harianto's statement, there are two concepts in translation process consisting of old concept and modern concept. Old concept translation means that the translation is just transferring the message from the source language into the target language. Whilst in modern concept which is stated by Nida and Taber (1974:33), they say that translating process used for: 
1. Analyzing or understanding the meaning, the concept, and the message of the source language.

2. Transferring the result of analysis into the similar message into the target language.

3. Restructuring the transferred message into good target language by equivalent words.

The translator should know the correct strategies and creative in choosing correct diction. Meanwhile, the film translator should give the target audience to experience the foreign language. However, the translator should put their knowledge and competence in their translation. The translator should find a way to express the meaning of the source language to acceptable and correct strategies in the target language. Furthermore, based on subtitling strategies theory from Gottlieb (1992:166) there are ten strategies that can be applied such as expansion, paraphrase, transfer, imitation, transcription, dislocation, condensation, decimation, deletion, and resignation. The translator can use the theory above to translate the subtitles in the movies or films.

Translator is someone who has ability to convert, interpret, and deliver the written idea from the source language (SL) to the target language (TL). In translating movies, a translator should knowing the correct strategies and be creative in choosing correct diction. Meanwhile, the movie translator should give the target audience to experience the foreign language and put their knowledge in their translation. In this case, the translator should transfer the source language (English) to the target language (Indonesia). (There are statements that correlate to the ability of translator should have according to Basnett 1991:8):

1. Accept the untranslatability of the source language phrase in the target language on the linguistic level

2. Accept the lack of a similar cultural convention in target language.

3. Consider the range of target language phrases available, having regard to the presentation of class,status,age, his relationship to the listeners and the context of their meeting in the source language.

4. Consider the significance of the phrase in its particular contextas a moment of high tension in the dramatic text.

5. Replace in the target language the invariant core of the source language phrase in its two referential systems of culture out of which the text has sprung.

Audiovisual translation is a specialized branch of translation which deals with the transfer of multimodal and multimedia texts into another language and culture. Audiovisual Translation is divided into two forms, consisting of Subtitling and Dubbing. "Subtitling is visual, involving the superposition of a written text into the screen. Dubbing, on the other hand is oral, it is one of a number of translation methods which makes use of the acoustic channel in screen translation" (Baker and Hochel, 1998:74).

Furthermore, the reason why the researchers chose Po's utterances because Po has the most conversations than others in the movie. "Kung Fu Panda" is a 2008 comedy action movie distributed by Paramount Pictures and produced by Dreamworks Animation. It was directed by Mark Osborne and John Stevenson. "Kung Fu Panda" first premiered in the United States of America on June, $6^{\text {th }} 2008$. The researchers chose this movie as the data research because the storyline is interesting and there are many famous actors or actress who dubbed on each character in this movie like Jake Blake (Po), Angelina Jolie (Tigress), Lucy Liu (Viper), and Jackie Chan (Monkey). Kung Fu Panda movie has received many awards, it won the Annie Awards for Best Character Design, Best Storyboarding, Best 
Music, Best Voice Acting, Best Writing, and many more. Meanwhile, this movie also received the Nickelodeon Kids Choice Award for Favorite Voice. Those Annie and Nickelodeon Awards were obtained in 2009. The movie tells the story about student of Master Shifu, named Po, Po is a lazy giant panda and the biggest fan of kung fu. Meanwhile, He has kindhearted goose father in his noodle eatery, his name is Mr. Ping. Po have a dream to be a kung fu master, his dream came true when he chosen by Master Oogway into the new dragon warrior to join with the furious five, and trained by Master Shifu to beat Tai Lung (the wicked snow leopard) as adoptive son, ex student of Master Shifu and save the world from all enemies.

Subtitle is a text of the language that has been translated from the dialogue in the movie, film, video, television program and usually displayed at the bottom of the screen when we play it. That subtitle may be a translation of a dialogue in a foreign language or written from a dialogue in the same language, to make the audience to understand more easily the language and help them to follow the dialogue in the movies or films. Based on theory from Baker (2001:247) subtitles are textual version of the dialogue in films and television programs, it can be defined as the transcription of film or TV dialogue presented simultaneously on the screen. Based on theory from Gottlieb, subtitles are displayed at the bottom of screen and in the middle position, the minimum duration of subtitle is 3 second and the maximum time of subtitle is 5 second. Then for two lines the duration is 7 second and the maximum is 8 second. For the one line, subtitle itself is consider 40 characters (35 characters in Europe) and for the second line is shorter than the first one, including of space and punctuation. Subtitles exist in two forms, it contains open subtitles (open to all and cannot be turned off by the viewer, such as karaoke song lyrics.) and closed subtitles (usually can be turned on/off or selected by the viewer, such as being DVD Bitmap subtitles and DVD Blu-ray subtitles).

Another arrangement to translate the subtitle is applying the subtitling strategies. As translation procedures, subtitling strategies is a technical devices in translation world. Meanwhile, subtitling is used to transfer the meaning of dialogues in one language into a text in another language. Based on subtitling strategies theory from Henrik Gottlieb (1992:166) there are ten strategies, consisting of expansion, paraphrase, transfer, imitation, transcription, dislocation, condensation, decimation, deletion, and resignation. The example of subtitling strategies can be summed up as follows:

\section{Expansion}

Expansion is a strategy which is used when the dialogue in the source language (SL) needs an explanation in the target language (TL) to make the audience more understand, especially language that consists of culture.

Example:

SL: Use your left!

TL: Gunakan tinju kirimu!

(Naomi Ventria Nauly Simanjuntak, 2013)

\section{Paraphrase}

Paraphrase is a strategy used by changing the construction of the source language (SL) into the target language (TL) but the meaning still maintained and easier to understand. 
Example:

SL: We're getting a ton of heat from the police out here on the video.

TL: Kita dapatkan pernyataan keras dari polisi disini tentang video itu. (Ineke Hartanto P, 2016)

\section{Transfer}

Transfer is a strategy used to translate the source language (SL) completely and correctly to the target language (TL).

Example:

SL: ...have many friends, many experiences.

TL: ...punya banyak teman, banyak pengalaman.

(Widiastuti, Ni Made Ayu and Ni Putu Krisnawati, 2010)

\section{Imitation}

Imitation is a strategy used to rewrite the word of original text. Imitation usually used to translate the name of character, city, places, name of magazine, journal, newspapers, name of company, institution and address.

Example:

SL: And her name was Maleficent.

TL: Dan namanya ialah Maleficent.

(Rr. Gustin Zora Aveline, 2015)

\section{Transcription}

Transcription is a strategy used to translate a language when there exist unusual term in the source language (SL), like nonsense language and third language.

Example:

SL: Jiu-jitsu, muay thai, and a thousand styles in between.

TL: Jiu-jitsu, muay thai, dan ratusan lainnya.

(Naomi Ventria Nauly Simanjuntak, 2013)

\section{Dislocation}

Dislocation is a strategy used when the source language (SL) employs some sort of special effect, for example a silly song in a cartoon film, where the translation of the effect is more important than the content.

Example:

SL: Spider-Pig, Spider-Pig, does whatever a Spider-Pig does, can he swing, from a web? No he can't, he's a pig, Look out! He is Spider Pig.

TL: Babi Laba-laba, Babi Laba-laba. Melakukan apapun yang dilakukan Babi Laba-laba. Dapatkah Ia berayun dari jaringnya?

Tidak bisa, dia seekor babi. Lihatlah. Dia seekor Babi Laba-laba.

(Astuti, 2009 in Simanjuntak, 2013) 


\section{Condensation}

Condensation is a strategy of translating by reducing the text from the source language (SL) to the target language (TL) without losing the original content.

Example:

SL: No, the day after her birthday.

TL: Tidak, sehari setelahnya.

(Rr. Gustin Zora Aveline, 2015)

\section{Decimation}

Decimation is omitting important element that are confusing the audience and some taboo words.

Example:

SL: I made a mistake! Shit!

TL: Aku salah

(Ineke Hartanto P, 2016)

\section{Deletion}

Deletion is deliberate exclusion of the entire source language and less important aspects. For example, the elimination of text like repetition of words.

Example:

SL: Did I read it? Yeah. I read it.

TL: Apa aku membacanya? Aku membacanya.

(Ineke Hartanto P, 2016)

\section{Resignation}

Resignation is a strategy used when the translator does not find the solution in translating the SL subtitle and that the meaning is inevitably lost.

Example:

SL: It begins when the object of your affection...

TL: NO TRANSLATION

(Widiastuti, Ni Made Ayu and Ni Putu Krisnawati, 2010)

\section{METHOD}

Descriptive qualitative method is used in this research for the subtitling strategies of Po's utterances in "Kung Fu Panda movie". Descriptive qualitative method is a research method to describe the object or subject of the research based on the phenomena or reality. The researchers chose descriptive qualitative method because the aim of this research is to explain the phenomena of translation, especially the subtitling strategies which are used in "Kung Fu Panda movie". The unit of analysis of this research is the utterances of Po, as a 
main character and then grouped into subtitle of "Kung Fu Panda movie". Both source and target language are English and Indonesian language as the data to be analyzed. The data of this research were taken from "Kung Fu Panda" original DVD distributed by Paramount Pictures and produced by Dreamworks Animation. This movie got score 82 from Rotten Tomatoes. "Kung Fu Panda" is American comedy action movie directed by Mark Osborne and John Stevenson, and released on 2008. The data of this research is 345 utterances of Po, consisting of English (SL) and Indonesian (TL) subtitle from the conversation of the original movie.

\section{RESULTS AND DISCUSSION}

This research data is Po's utterances in "Kung Fu Panda" movie. The researchers watched the "Kung Fu Panda" movie several times to note all English (SL) and Indonesian (TL) subtitles by the main character. The researchers only collected the dialogues that were said by Po as the main character in "Kung Fu Panda" movie and classified data based on subtitling strategies. Those can be seen in the chart below:

Table 4 Findings

\begin{tabular}{clcc}
\hline No & Translation Strategies & Data & Percentage \\
\hline 1 & Expansion & 19 & $5,51 \%$ \\
2 & Paraphrase & 22 & $6,38 \%$ \\
3 & Transfer & 186 & $53,91 \%$ \\
4 & Imitation & 26 & $7,54 \%$ \\
5 & Transcription & 10 & $2,90 \%$ \\
6 & Condensation & 36 & $10,43 \%$ \\
7 & Deletion & 46 & $13,33 \%$ \\
\hline TOTAL & $\mathbf{3 4 5}$ & $\mathbf{1 0 0 \%}$ \\
\hline
\end{tabular}

Table 4.1 show 345 Po's utterances found in Kung Fu Panda movie. The researchers found 345 subtitling strategies of Po's utterances in Kung Fu Panda movie. Those subtitling strategies are $19(5,51 \%)$ data using expansion strategies, $22(6,38 \%)$ data using paraphrase strategies, $186(53,91 \%)$ data using transfer strategies, $26(7,54 \%)$ data using imitation strategies, $10(2,90 \%)$ data using transcription strategies, $36(10,43 \%)$ data using condensation strategies, and $46(13,33 \%)$ data using deletion strategies. Transfer strategy has more frequency in Po's utterances in Kung Fu Panda movie, the percentage reaching $53,91 \%$ over half of Po's utterances. Transfer strategy is translated easier because this strategy translating the source language completely and accurately into the target language. So it is easy to make the audience understand from source language to target language with the original meaning from this movie.

Meanwhile, transcription has the least frequency in Po's utterances, the percentage is $2,90 \%$. Transcription strategy is found rarely because this strategy is used to translate a language when there exist unusual term in the source language, like nonsense language and third language. So it is difficult to find out transcription strategy in Kung Fu Panda movie. Based on the research, some subtitling strategies are used to translate Po's utterances in "Kung Fu Panda" movie. Discussions of each subtitling strategies are as follow: 


\section{Expansion}

Expansion is a strategy used when the dialogue in the source language (SL) needs an explanation in the target language (TL) to make the audience understand more, especially language that consist of culture. These are some example where the strategy is used:

Excerpt 1 (Utterance 26)

SL: Coming!

TL: Aku datang!

The strategy used in the utterance above is expansion strategy. This strategy is used to translate the source language "Coming!" into the target language "Aku datang!" The translator added the word " $a k u$ " in the target language because from the scene where the dialogue appears, Mr. Ping as Po's father in this movie told Po to finish his job. After that Po came down from the second floor to finish his job and then say "Coming!"So, the translator translated the utterance by adding the word "aku" to describe the persons involved in this scene, and that is refers to Po.

Excerpt 2 (Utterance 17)

SL: the Furious Five

TL: Lima Pendekar Terganas

The utterance above is translated into target language by using expansion strategy. This strategy is used to translate the source language "the Furious Five" into the target language "Lima Pendekar Terganas". The translator added the word "pendekar" in the target language, the word "pendekar" is added to describe five actors named Monkey, Mantis, Crane, Viper and Tigress who helped Po beat an enemies in this movie. So, by adding word "pendekar" in the target language, it would make the audience as the target understand clearly the subtitle between the context of this scene.

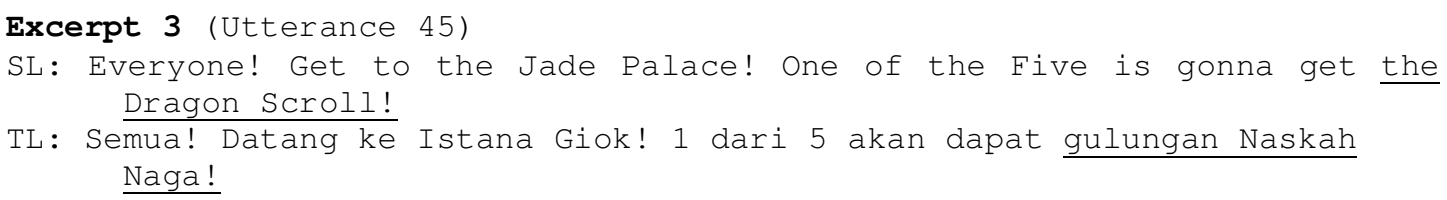

The translator used expansion strategy to translate the source language "Everyone! Get to the Jade Palace! One of the Five is gonna get the Dragon Scroll!" Into the target language "Semua! Datang ke Istana Giok! 1 dari 5 akan dapat gulungan Naskah Naga!" Because, if not using this strategy "the Dragon Scroll!" translated into "Gulungan Naga!" So, the translator added the word "Naskah" in the target language as the meaning from expansion strategy. The word "Naskah" is used to explain the meaning of the utterance "Dragon Scroll" in the source language because Po as the main character in this movie invite all customer to visit Jade Palace and see who are gonna get the Dragon Scroll.

Excerpt 4 (Utterance 182)

SL: I'm not like the five.

TL: Aku tak seperti kelompok lima itu.

The utterance above is translated into target language by using expansion strategy. This strategy is used to translate the source language "I'm not like the five." into the target language "Aku tak seperti kelompok lima itu". The utterance of "kelompok lima itu" refers 
to Monkey, Mantis, Crane, Viper and Tigress. If the translator not using this strategy "the five" translated into "kelima". In this scene a dejected Po is standing under a peach tree on a hill and Oogway approaches with a glowing lantern. Po said to Oogway that he is not upset and tells that the five totally hate him, after that Po sit down and then Oogway look at him for a moment.

Excerpt 5 (Utterance 220)

SL: Try my dad's Secret Ingredient Soup. He knows the secret ingredient.

TL: Kau harus coba Sup Resep Rahasia ayahku. Dia tahu bumbu rahasianya.

The strategy used in the utterance above is expansion strategy. The translator use this strategy to translate the source language "Try my dad's Secret Ingredient Soup. He knows the secret ingredient" into the target language "Kau harus coba Sup Resep Rahasia ayahku. Dia tahu bumbu rahasianya". If the translator not using expansion strategy "Try my dad's Secret Ingredient Soup" translated into "coba Sup Resep Rahasia ayahku". The translator added sentence "Kau harus" in the target language because in this scene Po as the main character told all his friend in kitchen that they should try the secret ingredients soup of his father.

\section{Paraphrase}

Paraphrase is a strategy used by changing the construction of the source language (SL) into the target language (TL) but the meaning still maintained and easier to understand. These are some example where the strategy is used:

Excerpt 6 (Utterance 138)

SL: I'm a blur. You've never seen bear style.

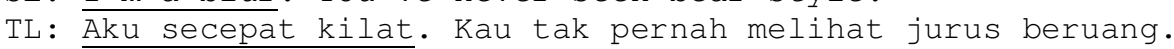

The strategy used in the utterance above is paraphrase strategy. It occurs in the source language "I'm a blur. You've never seen bear style" which is translated into "Aku secepat kilat. Kau tak pernah melihat jurus beruang" in the target language. "I'm a blur" is translated literally into "Aku kabur". But, it didn't sound natural because, in this scene when Po did an exercise with puppet, he wanted to show that his movements fast as lightning. So, the translator translated the source language "I'm a blur" into "Aku secepat kilat" in the target language because it sounds more natural toward the situation in this scene.

Excerpt 7 (Utterance 38)

SL: Why didn't you?

TL: Kenapa kau tak minggat?

The paraphrase strategy is used to translate the source language "Why didn't you?" into the target language "Kenapa kau tak minggat?". If the source language is translated literally, it says "mengapa tidak kamu?". On the other hand, the utterance "Kenapa kau tak minggat?" means to represent the meaning of "Why didn't you?" in the source language. In this conversation, the main character who talked is Po. The utterance occurs when Po give a suggestion to his father who thought about running away and learning how to make tofu by saying "Why didn't you?". If the translator translated it into "mengapa tidak kamu?" instead, this meaning is not suitable with the context of situation on the scene. So, the translator has chosen the utterance "Kenapa kau tak minggat?" to represent the meaning of 
"Why didn't you?" in this subtitle to make the audience easier to understand in the target language.

Excerpt 8 (Utterance 132)

SL: OK. I just ate, so I'm still digesting.

TL: Baiklah. Aku baru saja makan, biar agak turun dulu.

The utterance above used paraphrase strategy to translate the source language and target language. It occurs in the source language" so I'm still digesting" which is translated into "biar agak turun dulu" in the target language. "so I'm still digesting" is translated literally into "jadi aku masih mencerna". But, it didn't sound natural because, in this scene Po still hesitate to join exercise in the jade palace, and then he said "so I'm still digesting" as the reason to postpone an exercise. So, the translator translated the source language "so I'm still digesting" into "biar agak turun dulu" in the target language because it sounds easier to understand and more natural.

Excerpt 9 (Utterance 301)

SL: OK, here goes.

TL: Baik, aku akan baca.

The paraphrase strategy is used to translate the source language "OK, here goes" into the target language "Baik, aku akan baca". If the source language is translated literally, it says "Baik, ini dia". On the other hand, the utterance "aku akan baca" means to represent the meaning of "here goes" in the source language. In this scene, Master Shifu as Po's teacher take the dragon scroll and give it to Po as the dragon warrior chosen by Master Oogway. After that Po said "OK, here goes" and start to read the dragon scroll, but he was surprised that the dragon scroll was blank. So, the translator used the utterance "aku akan baca" to represent the meaning of "here goes" in this subtitle to make the audience easier to understand in the target language.

Excerpt 10 (Utterance 306)

SL: Come on! Face it, he picked me by accident.

TL: Jangan konyol! Terima kenyataan, dia cuma kebetulan memilihku.

The translator used paraphrase strategy to translate the utterance above. It occurs in the source language "Come on! Face it, he picked me by accident"which is translated into "Jangan konyol! Terima kenyataan, dia cuma kebetulan memilihku" in the target language. "Come on! Face it" is translated literally into "Ayo! Hadapilah". But, it didn't sound natural and not suitable with the context of situation because from the scene where the dialogue appears, Po opened the dragon scroll and see it's empty, he didn't believe that he was a dragon warrior chosen by Master Oogway and assumes that Master Oogway picked him by accident. So, the translator has chosen the utterance "Jangan konyol! Terima kenyataan" to represent the meaning of "Come on! Face it" in this subtitle to make the audience easier to understand in the target language.

The translator used paraphrase strategy to translate the source language because the translator wants to make the utterance sounds natural and make the audience easier to understand what the actor means. The translator also used more expressive words to overcome the problem in translation by using this strategy. 


\section{Transfer}

Transfer is a strategy used to translate the source language (SL) completely and correctly into the target language (TL). These are some example where the strategy is used:

Excerpt 11 (Utterance 1)

SL: Legend tells of a legendary warrior

TL: Legenda mengisahkan tentang pendekar legendaris

The dialogue above used transfer strategy to translate the source language and target language. It can be seen from the utterance "Legend tells of a legendary warrior" in the source language which translated into the target language "Legenda mengisahkan tentang pendekar legendaris". In this scene Po had a dream that he is a legendary warrior who save the world from enemies. From the context of the scene there is no change of the meaning from both of the language because the dialogue is uttered by the actors that showed the real act from the scene in this movie. So, the meaning of the subtitle and the context of this scene is suitable.

Excerpt 12 (Utterance 37)

SL: Something besides noodles?

TL: Sesuatu selain mie?

From the utterance in this scene, it can be seen that the source language and target language used transfer strategy. The utterance "Something besides noodles?" in the source language is translated into "Sesuatu selain mie?"in the target language without adding or deleting some word. The translator translated literally in the utterance above and doesn't change the form of the source language "Something besidesnoodles?" into the target language "Sesuatu selain mie?". Both of them still become interrogative form. From the context of this scene, the utterance doesn't change the interrogative form in the dialogue which is talked by the main character named Po to ask his father the reason why he still make noodles. In the target language the form and the meaning of the subtitle with the context does not change.

Excerpt 13 (Utterance 33)

SL: Careful! That soup is sharp.

TL: Hati-hati! Sop itu tajam.

The translator used transfer strategy to translate the utterance from the source language into the target language. The translator translated the utterance "Careful! That soup is sharp" into "Hati-hati! Sop itu tajam" without adding or deleting some words in the source language and target language. It can be seen on the scene when Po served a bowl of noodles to the customer. So, the meaning of the utterance has the same meaning of the subtitle and the context story in this scene.

Excerpt 14 (Utterance 21)

SL: Because when you're facing the 10,000 demons of Demon Mountain.

TL: Karena ketika kau menghadapi 10.000 iblis dari gunung iblis.

From the utterance above, it can be seen that the source language and the target language used transfer strategy. The utterance "Because when you're facing the 10,000 demons of Demon Mountain" in the source language is translated into "Karena ketika kau menghadapi 10.000 iblis dari gunung iblis" in the target language without adding or 
deleting some word. It can be seen on the scene when Po and the furious five face the enemies and attack together in his dream.

Excerpt 15 (Utterance 217)

SL: If he could read my mind, he will say, "What?"

TL: Jika dia bisa membaca pikiranku, dia akan bilang, "Apa?"

Transfer strategy is used to translate the utterance above. The utterance "If he could read my mind, he will say, "What?"'in the source language which is translated into the target language "Jika dia bisa membaca pikiranku, dia akan bilang, "Apa?" without adding and deleting some word. It can be seen on the scene when Po is cooking and telling a story for the furious five in the kitchen. From the context of the scene there is no change of the meaning from both of the language because the dialogue is uttered by the actors that showed the real act from the scene in this movie. So, the meaning of the subtitle and the context of this scene is suitable. From the excerpt above, the translator used transfer strategy because all the words were translated literally. There is no added explanation or deletion of words in those excerpt. There is no change of the words in the source language to the target language here, it can be seen from the excerpt above, both source language and target language are translated completely, correctly and refers to the same meaning.

\section{Imitation}

Imitation is a strategy used to rewrite the word of original text. Imitation usually used to translate the name of character, city, places, name of magazine, journal, newspaper, name of company, institution and address. These are some example where the strategy is used:

Excerpt 16 (Utterance 44)

SL: Master Oogway choosing the Dragon Warrior! Today!

TL: Guru Oogway memilih Pendekar Naga! Hari ini!

Imitation strategy is used to translate the source language "Master Oogway choosing the Dragon Warrior! Today!" into the target language "Guru Oogway memilih Pendekar Naga! Hari ini!". The translator rewrote the word "Oogway" into the target language. Based on this movie, "Oogway" is a name of the old turtle who chose Po to be a dragon warrior and Shifu's teacher.

Excerpt 17 (Utterance 116)

SL: Developed by Master Wuxi in the Third Dynasty.

TL: Dikembangkan oleh Guru Wuxi dari Dinasti ke-3.

The translator used imitation strategy to translate the source language "Developed by Master Wuxi in the Third Dynasty" into the target language "Dikembangkan oleh Guru Wuxi dari Dinasti ke-3". The translator rewrote the word "Wuxi" into the target language. Based on the movie, "Wuxi" is a name of the legendary warrior who created the Wuxi Finger Hold.

Excerpt 18 (Utterance 212)

SL: You may be the scariest bandit in Haijin Province.

TL: Kau mungkin bandit tersadis di Provinsi Haijin.

Name of place above is translated into imitation strategy. The translator translated the source language "You may be the scariest bandit in Haijin Province". into the target language "Kau mungkin bandit tersadis di Provinsi Haijin". The translator rewrote the 
word "Haijin" into the target language. "Haijin" is a name of province which located in China.

Excerpt 19 (Utterance 233)

SL: I'm gonna stop Tai Lung.

TL: Aku akan hentikan Tai Lung.

The utterance above used imitation strategy to translate the source language "I'm gonna stop Tai Lung". into the target language "Aku akan hentikan Tai Lung". The translator rewrote the word "Tai Lung" into the target language. Based on this movie, "Tai Lung" is a name of the wicked snow leopard, Po's enemy and former Shifu's student.

Excerpt 20 (Utterance 309)

SL: But Shifu, he'll kill you.

TL: Tapi Shifu, dia akan membunuhmu.

The translator used imitation strategy to translate the source language "But Shifu, he'll kill you". into the target language "Tapi Shifu, dia akan membunuhmu". The translator rewrote the word "Shifu" into the target language. Based on this movie, "Shifu" is a name of the red panda and Po's teacher who trained him to be a dragon warrior.

Based on the excerpt above we can conclude the translator used the imitation strategy when there was a name of character, person, place, country, etc found in the source language. The translator didn't translate them into another word. So, the target language will maintain the same word with the source language of the utterance.

\section{Transcription}

Transcription is a strategy used to translate a language when there exist unusual term in SL, like nonsense language and third language. These are some example where the strategy is used:

Excerpt 21 (Utterance 7)

SL: Shashabooey!

TL: Shashabooey!

The utterance "Shashabooey!" in the source language is translated into "Shashabooey!" in the target language by using transcription strategy. The word in the source language that used this strategy is "Shashabooey!". The translator used this strategy because this word is nonsense language. By using nonsense language, the word is not included into transcription strategy which is not translated into the target language. Based on this movie "Shashabooey!" means Po's utterance when he attacking the boss gang and all enemies in bar by punches and kicks them until flying in the sky.

Excerpt 22 (Utterance 47)

SL: This is the greatest day in Kung Fu history! Just go!

TL: Ini hari terbesar dalam sejarah Kung Fu! Silahkan pergi!

Transcription strategy is used to translate the source language "This is the greatest day in Kung Fu history! Just go!" into the target language "Ini hari terbesar dalam sejarah Kung Fu! Silahkan pergi!". The word in the source language that used this strategy is "Kung $F u$ "(martial arts from China). The translator used this strategy because this word is third language. By using third language, the word included into transcription strategy was not translated into the target language. The third language that used in this utterance is from 
Chinese language and the translator does not find the meaning of "Kung $F u$ " in the target language.

Excerpt 23 (Utterance 12)

SL: Kablooey!

TL: $\overline{\text { Kablooey! }}$

The utterance "Kablooey!" in the source language is translated into "Kablooey!" in the target language by using transcription strategy. The word in the source language that used this strategy is "Kablooey!". The translator used this strategy because this word is nonsense language. By using nonsense language, the word included into transcription strategy was not translated into the target language. Based on this movie, "Kablooey!" means Po's utterance when he twists like tornado and kicks the ninjas rapidly.

Based from the excerpt above we can conclude that the translator used the transcription strategy to translate a language when there exist unusual term in SL. For example, the use of a nonsense language and third language.

\section{Condensation}

Condensation is a strategy of translating by subtracting the target language (TL) from the source language (SL) without reducing the meaning. In short, reducing the text from the source language (SL) to the target language is applied (TL) without losing the original content. These are some example where the strategy is used:

Excerpt 24 (Utterance 3)

SL: He traveled the land in search of worthy foes.

TL: Dia berkelana untuk mencari musuh yang tangguh.

Based on the scene, the legendary warrior traveling in China looked for the strongest foes to fight with him. The utterance "He traveled the land" in the source language is translated into "Dia berkelana" in the target language by using condensation strategy. Condensation strategy is used by the translator to make the text brief by missing unnecessary sentence. It was found in the utterance the land in the source language. The utterance "the land" which means "tanah" was not translated into Indonesian subtitle. Although it was not translated, the subtitle still conveyed the meaning of the source language.

Excerpt 25 (Utterance 130)

SL: You're bigger than your action figure. Except you Mantis, you're same.

TL: Kalian lebih besar dari boneka kalian. Kecuali kau Belalang, sama.

In this scene Po as the new dragon warrior meet Monkey, Mantis, Crane, Viper, Tigress in the room for exercises and compare the furious five with his action figures. The utterance above used condensation strategy to translated the source language "you're same" into "sama" in the target language. It can be seen on the utterance "you're" in the source language which means "kamu adalah" was not translated into Indonesian subtitle. So, the translator used condensation strategy to reducing the utterance in the target language without changing the meaning of the source language.

Excerpt 26 (Utterance 8)

SL: He was so deadly in fact

TL: Dia sangat berbahaya 
Condensation strategy is used to translate the source language "He was so deadly in fact" into "Dia sangat berbahaya" in the target language. It can be seen on the utterance "deadly in fact" in the source language. The utterance "deadly in fact" which means "fakta yang mematikan" was not translated into Indonesian subtitle. In this scene Po was dreaming and tell a story about himself when he become to a legendary warrior who are very dangerous and then accepted the gang boss challenge to fight with him in bar. So, the translator used condensation strategy to make the target language briefer without changing the meaning of the source language.

Excerpt 27 (Utterance 40)

SL: Excuse me. Pardon me. Sorry.

TL: Maaf.

In this scene Mr. Ping as Po's father in the movie told Po to delivere a bowl of noodles to the customer. But Po didn't serve the customer well, because when Po delivered a bowl of noodles to the customer his belly get stuck between two tables and in his attempt to free himself, Po accidentally put his tail into a rabbit family's noodle bowl and making the rabbit children cry. Condensation strategy is used to translate "Excuse me. Pardon me. Sorry" in the source language into "Maaf" in the target language. It can be seen in the sentences "Excuse me" and "Pardon me", both of them was not translated into Indonesian subtitle. So, the translator used this strategy to shorten the utterance in the target language without losing the meaning of the source language.

Excerpt 28 (Utterance 131)

SL: Are they gonna watch? or should I wait till they get back to work?

TL: Mereka menonton? Atau aku tunggu sampai mereka kembali bekerja?

Based on the scene Master Shifu invite Po to the jade palace for committed some exercise as the new dragon warrior, Po was very exciting because he meet the furious five in the jade palace and hope the furious five see his exercises. The translator used condensation strategy to translate the source language "Are they gonna watch?" into "Mereka menonton?" in target language. It can be seen in the sentences "Are" and "gonna" which means "Apakah" and "akan" was not translated into Indonesian subtitle. So, the translator used condensation strategy to make the target language briefer without changing the meaning of the source language.

Based from the excerpt above we can conclude that the translator used the condensation strategy to make the target language briefer by missing unnecessary utterances in the source language, it can be deleted without altering the meaning of the source language because the real aim of the story must be conveyed.

\section{Deletion}

Deletion is deliberate exclusion of the entire source language and less important aspects. For example, the elimination of text, repetition of words. These are some example where the strategy is used:

Excerpt 29 (Utterance 74)

SL: I lied. I don't dream about noodles, Dad.

TL: Aku bohong. Aku tak bermimpi tentang mie.

Deletion strategy is used to translate the utterance above. This strategy is used to delete the word "Dad" in the source language "I lied. I don't dream about noodles, Dad"into "Aku 
bohong. Aku tak bermimpi tentang mie" in the target language. The word "Dad" is not displayed and translated because based from the scene when the dialogue occurred Po was talking to his father in their restaurant. So, deleting the word "Dad" has no effect and does not corrupt the meaning in the target language.

Excerpt 30 (Utterance 35)

SL: Dad, Dad, Dad, it was just a dream.

TL: Ayah, itu hanya mimpi.

In this conversation, the dialogue between Po and his father Mr. Ping. After wake up Po helped his father make noodles in his restaurant and tell that last night he had a dream about noodles but, Po lied to his father about his dream, the truth is he had a dream about legendary warrior. The utterance above used deletion strategy to delete the word "Dad" in the source language "Dad, Dad, Dad, it was just a dream". In the target language, the second and the third word "Dad" is not found. Instead, the word "Ayah" is used to represent the meaning word in the source language. This strategy deletes two of word "Dad" because it is not translated thrice into the target language and it makes the target language simple.

Excerpt 31 (Utterance 273)

SL: Oh, great, cause I am hungry.

TL: Bagus, karena aku lapar.

The translator used deletion strategy to translate the utterance above. This strategy is used to delete the word "Oh" in the source language "Oh, great, cause I am hungry" into "Bagus, karena aku lapar" in the target language. The word "Oh" is not found in the target language because it is unnecessary word to translate and display. Based on the scene, the word "Oh" expressed that Po is tempted to eat Bakpao (steamed bun stuffed with meat or other ingredients) from Master Shifu. So, without adding the word "Oh", the audience still understand the utterance which occurs in this scene.

Excerpt 32 (Utterance 61)

SL: I'm coming! Wait, wait!

TL: Aku datang! Tunggu!

Based on the scene Po went to the jade palace to see the furious five which one of them gonna get the dragon scroll. After arrived in the jade palace, the door was closed and it makes Po upset. But Po have an idea to see the furious five by using a rocket fireworks to enter the jade palace. The utterance above used deletion strategy to delete the word "wait!" in the source language "I'm coming! Wait, wait!'. In the target language, the second word "wait!" is not found. Instead, the word "Tunggu!" is used to represent the meaning word in the source language. This strategy deletes one of word "wait!" because it is not translated twice into the target language.

Excerpt 33 (Utterance 160)

SL: I know. I know. You're right.

TL: Aku tahu. Kau benar.

In this conversation, the dialogue is between Po as the new dragon warrior and Crane as the furious five. Before going to sleep Po met the Crane doing some exercises in his room, Po was very noisy and told Crane that he is the big fan of the furious five, but Crane feels his exercise was disturbed by Po. The translator used the deletion strategy to delete the sentence "I know" in the source language "I know. I know. You're right". In the target language, the second sentence "I know" is not found. Instead, the sentence "Aku tahu" is 
used to represent the meaning sentence in the source language. This strategy deleted one of sentence "I know" because it is not translated twice into the target language and it makes the target language simple. Based on the excerpt above we can conclude that the translator used the deletion strategy to eliminate the less important aspects of a text like repetition of words and filler words.

\section{CONCLUSION}

This chapter covers conclusion of the study and suggestion that might have benefit and input for everyone who wants to conduct a research relating to this study. Based on data analysis that have been finished by the researcher, it has been concluded that there are 345 $(100 \%)$ data of Po's utterances in Kung Fu Panda movie subtitle which have been analyzed based on subtitling strategies theory from Gottlieb (1992:166). The researchers found 345 subtitling strategies of Po's utterances in Kung Fu Panda movie. Those subtitling strategies are $19(5,51 \%)$ data using expansion, $22(6,38 \%)$ data using paraphrase, $186(53,91 \%)$ data using transfer, $26(7,54 \%)$ data using imitation, $10(2,90 \%)$ data using transcription, 36 $(10,43 \%)$ data using condensation, and $46(13,33 \%)$ data using deletion.

From this movie, several strategies such as dislocation, decimation, and resignation aren't used by the researcher. Transfer strategy has the most frequency in Po's utterances in Kung Fu Panda movie, the percentage reaching 53,91\% over half of Po's utterances. Transfer strategy is easier to translated because this strategy translating the source language completely and accurately into the target language. So it is easy to make the audience understand from source language to target language with the original meaning from this movie. Meanwhile, transcription has the least frequency in Po's utterances, the percentage is $2,90 \%$. Transcription strategy is found rarely because this strategy is used to translate a language when there exist unusual term in the source language, like nonsense language and third language. So it is difficult to find out transcription strategy in Kung Fu Panda movie.

\section{REFERENCES}

Aveline, Rr. Gustin Zora. (2015). Subtitling Strategies and Translation Readability of the Indonesia Subtitle of Maleficent Movie. Semarang: Universitas Negeri Semarang.

Baker, M.,\& Hochel, B. (1998). Routledge Ecyclopedia of Translation Studies.London:Routledge.

Baker, M. (2001). Routledge Ecyclopedia of Translation Studies. New York:Routledge.

Basnett, S. (1991). Translation Studies. Third Edition. New York: Routledge.

Gottlieb, H. (1992). Subtitling. "A New University Discipline”. In Dollerup \& Loddegaard (eds). Teaching Translation and Interpreting: Training, talent and experience. Philadelpia: John Benjamins Publishing Company.

Larson, Mildred L. (1991). Translation: Theory and Practice, Tension and Interdependence.

Nida, E.A., \& Taber, C.R. (1974). The Theory and Practice of Translation. Leiden: E.J. Brill. 
Putri, I.H. (2016). An Analysis of Subtitling Strategies Used in Nightcrawler Movie. Tulungagung: IAIN Tulungagung.

Simanjuntak, N.V.N. (2013). Subtitling Strategies in Real Steel Movie. Semarang: Universitas Dian Nuswantoro.

Widiastuti, Ni Made Ayu and Ni Putu Krisnawati. (2010). The Translation Analysis of the English Film Subtitle 'Eat, Pray, Love' into Indonesian. 1-5.

\section{WEBSITES}

https://en.wikipedia.org/wiki/Kung_Fu_Panda_(film)

https://subscene.com/subtitles/kung-fu-panda

https://translationjournal.net/journal/32film.htm

https://www.dreamworksanimation.com

https://www.slideshare.net 